\section{Multidisciplinary \\ SCIENTIFIC JOURNAL OF MARITIME RESEARCH}

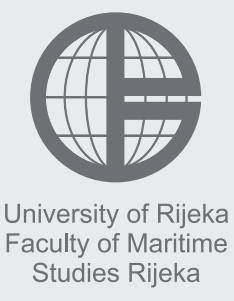

Multidisciplinarni

znanstveni časopis

POMORSTVO

https://doi.org/10.31217/p.32.2.9

\title{
Emission Inventory of Marine Traffic for the Port of Zadar
}

\author{
Vlatko Knežević1, Radoslav Radonja², Čedomir Dundović \\ ${ }^{1}$ University of Zadar, Maritime Department, M. Pavlinovića 1, 23000 Zadar, Croatia, e-mail: vknezevi1@unizd.hr \\ ${ }^{2}$ University of Rijeka, Faculty of Maritime Studies, Studentska 2, 51000 Rijeka, Croatia, e-mail: radonja@pfri.hr; dundovic@pfri.hr
}

\section{ARTICLE INFO}

Preliminary communication Received 3 November 2018 Accepted 8 December 2018

\section{Key words:}

Emission inventory

Exhaust gases

Air pollutants

The port of Zadar ships and 20\% from cargo ships.

\section{Introduction}

A significant energetic and technological growth of seaports has had a major impact on the coastal ecosystem. Due to a continuous increase of the maritime transport, more and more attention has been given to the development of the new eco-efficient solutions and the reduction of exhaust gases from marine engines. The recent studies $[16,13]$ have shown that the emission of air pollutants $\left(\mathrm{NO}_{x^{\prime}} \mathrm{SO}_{x^{\prime}} \mathrm{PM}\right)$ and greenhouse gasses $\left(\mathrm{CO}_{2}\right)$ has doubled in the last two decades. The annual amount of $\mathrm{CO}_{2}$ emission from overall maritime transport is 1.2 billion tons, which makes $4.5 \%$ of global $\mathrm{CO}_{2}$ emission. Anthropologically caused increased atmospheric carbon dioxide emissions (the expected increase is $150 \%$ by 2050 [24]) are causing visible changes in both temperature increase and acidification of inland waters and oceans. The share of the shipping transport in the global emissions has been estimated to $15 \%$ for $\mathrm{NO}_{\mathrm{x}}$ and $4.9 \%$ for $\mathrm{SO}_{\mathrm{x}}$ [15]. The consequences of fine particulate matter (PM) have been considered a risk for a premature lung cancer and cardiovascular diseases [20]. The global emissions research [5] has shown that the highest concentrations have been present in the Northern Hemisphere due to a large number of the inter- national routes. It is considered that in the following years the total amount of harmful pollutants from the international marine traffic in European coastal areas could reach land-based emissions. [6]

Many studies have focused on the estimation of the port-emission inventories with the purpose of increasing the control of the exhaust gases and suggesting the adequate regulatory measures for the local costs and the emission reduction $[3,4,15$, and 18]. The emission inventory methodologies have been mostly based on a ship activity data and type of the fuel used. The automatic identification system $(A I S)$ has been used for gathering necessary data such as: the position and speed of a ship, cruising time, the engine load factor etc. The system has been introduced by the IMO, [24] for the purposes of the shipping management and safety at sea, but also as the one that could be applied for the annual emission-estimation for the particular ports.

Croatian ports of Dubrovnik, Zadar and Split have been considered important tourist destinations for cruise ships. The annual growth of the marine traffic has been the cause of greater exhaust gases emissions in these areas. The port of Zadar has been chosen for this research due to the implementation of a new development plan [22]. 
Furthermore, Zadar became the best tourist destination in Europe in 2016 [25], which has resulted in the growth of tourist traffic. The port emission inventory is necessary both for a strategic planning of a port's development that has to be ecologically acceptable and for the future measures in order to reduce emissions. No such research has been conducted so far.

\section{Study Area and Port Data Analysis}

The emission assessment in this paper includes Zadar coastal area and the port of Zadar infrastructure, as the most ecologically affected area. The assessment emission area has been separated into three sections: cruising in the reduce speed zone (the island of Grujica - the port of Zadar), the passenger port (Old City- Gaženica port) and Zadar cargo port.

\subsection{Reduce Speed Zone Area}

Term "reduce speed zone" is defined as the distance a ship travels from the beginning of the pilotage to the port. The pilotage includes the distance from the island of Grujica to the breakwater of the port of Zadar, which totals $35.245 \mathrm{Nm}(64.588 \mathrm{~km})$ (Figure 1). During the pilotage, the average speed of a ship is reduced but the cruising time to a port is increased, thus causing higher emissions. The estimated maximum safe speed in the reduce speed zone is 9-12 knots, i.e. 11 knots for container and cruise ships and 9 knots for all other types of ships. [9]

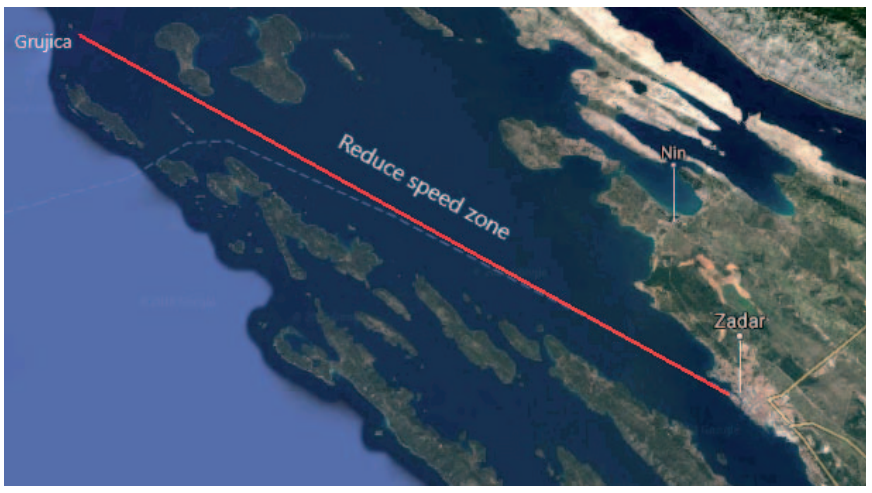

Figure 1 Reduce speed zone - pilotage of ships (Grujica-Zadar) [authors]

\subsection{Marine Traffic in the Port of Zadar}

The port emission inventory includes overall international traffic of cargo and passenger ships in the period from January to December 2017. Ships under 500 GT such as fishing vessels, yachts, catamarans and local tourist boats haven't been included in the emission inventory. The marine traffic flow has been systemized in table 1 according to the data provided by Port of Zadar Authority and Luka Zadar Ltd. [22]
Table 1 Marine traffic in the port of Zadar for the period between January and December 2017

\begin{tabular}{|l|c|l|c|}
\hline \multicolumn{4}{|c|}{ THE PORT OF ZADAR } \\
\hline \multicolumn{2}{|c|}{ Cargo port } & \multicolumn{2}{c|}{ Passenger port } \\
\hline \multicolumn{1}{|c|}{ Vessel type } & Number & \multicolumn{1}{c|}{ Vessel type } & Number \\
\hline General Cargo & 56 & General Cargo & 0 \\
\hline Bulk Carrier & 4 & Bulk Carrier & 0 \\
\hline Tanker & 13 & Tanker & 0 \\
\hline Reefer & 5 & Reefer & 0 \\
\hline Container Ship & 0 & Container Ship & 0 \\
\hline Cruise Ship & 0 & Cruise Ship & 108 \\
\hline
\end{tabular}

\section{Methodology}

There are two methods of the emission assessment from marine engines. The first one is the "top-down" method and it has been based on the data on the total amount of marine fuel sold and the fuel emission factor. This method has been considered unreliable especially on the global scale due to the inconsistent information on the fuel sold or consumed. For the purposes of this paper, the second method, i.e. the "bottom-up" method has been used to estimate the amount of emission. It has taken into consideration all the ship's particulars (installed main and auxiliary engine power, the load factor, and the emission factor) and movement data (at sea, during manoeuvring, at berth) [8]. Some emission studies have been taking into consideration the influence of waves, wind and currents, which may result in the $10-20 \%$ fuel consumption increase, [20]. However, this estimation has not been taken into consideration, due to relatively short and undemanding voyage. The emission assessment from container terminals, $[21,19]$ usually includes the emission from mobile cargo transport units and stationary cargo handling equipment, but they could have been disregarded here, taking into consideration the overall traffic.

\subsection{Emission Estimate Equations}

The total emission for a particular trip can be determined by summing all the ship's activities (navigation, manoeuvring and hotelling). These activities have a different impact on the fuel consumption and the exhaust gases emission [17]. The emission for the overall trip can be calculated as:

$$
E_{\text {trip }}=E_{\text {at sea }}+E_{\text {maneuvering }}+E_{\text {hotelling }}[g]
$$

For each ship movement at sea, the emission has been calculated as follows:

$$
\begin{aligned}
& E_{\text {at sea }}=\frac{D(\mathrm{~km})}{v(\mathrm{~km} / \mathrm{h})} \cdot\left[\left(M E(k W) \cdot L F_{M E}(\%) \cdot E F(\mathrm{~g} / \mathrm{kWh})+\right.\right. \\
& +\left(A E(k W) \cdot L F_{A E}(\%) \cdot E F(\mathrm{~g} / K W h]\right.
\end{aligned}
$$


For each ship calling the port, the emission for hotelling and manoeuvring activities has been calculated as follows:

$E_{\text {in port and maneuvering }}=T(h) \cdot\left[\left(M E(k W) \cdot L F_{M E}(\%) \cdot\right.\right.$

$\cdot E F(g / k W h)+\left(A E(k W) \cdot L F_{A E}(\%) \cdot E F(g / K W h]\right.$

where: D - Distance travelled; $\mathrm{v}$ - Average ship speed; ME - Main engine power; $\mathrm{LF}_{\mathrm{ME}}$ - Main engine load factor; $\mathrm{AE}$ - Auxiliary engine power; $\mathrm{LF}_{\mathrm{AE}}$ - Auxiliary engines load factor; EF - Emission factor, depending on the type of fuel and the engine speed; $\mathrm{T}$ - Average time spent at berth or manoeuvring per calling

\subsection{Fuel type}

The exhaust gases emissions and the emission factors significantly depend on the type of the fuel used. Sulphur and carbon content of the fuel affects the emission assessment of $\mathrm{SO}_{x}$ and $\mathrm{CO}_{2}$, depending on the area of navigation. The carbon content of the fuel is based on the Lloyds Register [23] data, which estimates $86,5 \%$ for all distillates. The sulphur content has been defined by EU Directive 2016/802, which requires that marine fuel sulphur content does not exceed $0,1 \%$ by mass in the internal waterways and ports of the EU. In addition, this has been based on the assumption that low sulphur fuels are used and $\mathrm{SO}_{2}$ reduction technologies (Sulphur scrubber) are not installed on any ship.

\subsection{Engine Details}

The data on the main and the auxiliary engines of all the vessels for the Port of Zadar have been obtained from the available information in the database [21, 22]. The data collected have shown that all cargo ships were mechanically driven by diesel engines (70\% four-stroke, $30 \%$ two-stroke), unlike cruise ships which had diesel-electric propulsion (except for 2 cruise ships with the gas turbines). In the cases of diesel-electric propulsion, where auxiliary engines power has not been defined from total generated power, the ratio of $27.8 \%(0.278)$ of MCR (Maximum Continuous Rating) was used. [9]

\subsection{Engine Load Factor}

Determining the estimated percentage load of the maximum continuous rating (MCR) of main and auxiliary engine depends on different ships activities (at sea, manoeuvring, at berth) and the actual speed. It is assumed that the load factor of the main engines is $80 \%$ while cruising, 20\% during manoeuvring and in port (at berth) when the engines are not running (except for tankers where the load factor is $20 \%$ due to the usage of pumps) [7]. According to the research [9], the auxiliary engine load factor depends on the type and activity of a ship and the assumption that they are running at all the times (except in port, while using high voltage shore connections, which in this case has not been applied). In addition, it appears that cruise ships employ high auxiliary engine load factor during manoeuvring due to the engagement of bowthrusters and electricity supply maintenance. The auxiliary engine load factors have been presented in Table 2.

Table 2 Auxiliary engine load factor, [9]

\begin{tabular}{|l|c|c|c|c|}
\hline \multicolumn{1}{|c|}{ Vessel type } & Cruise & RSZ $^{*}$ & Manoeuvre & Hotel \\
\hline General cargo & 0.17 & 0.27 & 0.45 & 0.22 \\
\hline Bulk carrier & 0.17 & 0.27 & 0.45 & 0.22 \\
\hline Container ship & 0.13 & 0.25 & 0.50 & 0.17 \\
\hline Cruise ship & 0.8 & 0.8 & 0.8 & 0.8 \\
\hline Tanker & 0.13 & 0.27 & 0.45 & 0.67 \\
\hline Reefer & 0.20 & 0.34 & 0.67 & 0.34 \\
\hline RO-RO & 0.15 & 0.30 & 0.45 & 0.30 \\
\hline
\end{tabular}

${ }^{*}$ Reduce speed zone

Table 3 ME emission factors (g/kWh) 'at sea', 'while manoeuvring, 'at berth', [8]

\begin{tabular}{|c|c|c|c|c|c|c|}
\hline \multicolumn{7}{|c|}{ At sea } \\
\hline Engine type/fuel type & $\mathrm{NO}_{x}$ pre-2000 engine & NOx post-2000 engine & $\mathrm{SO}_{2}$ & $\mathrm{CO}_{2}$ & VOC & PM \\
\hline $\mathrm{SSD} / \mathrm{MGO}$ & 17.0 & 14.1 & 0.7 & 588 & 0.6 & 0.3 \\
\hline SSD/MDO & 17.0 & 14.1 & 5.6 & 588 & 0.6 & 0.3 \\
\hline MSD/MGO & 13.2 & 11.0 & 0.8 & 645 & 0.5 & 0.3 \\
\hline MSD/MDO & 13.2 & 11.0 & 6.2 & 645 & 0.5 & 0.4 \\
\hline GT/MGO & 5.7 & 4.7 & 1.2 & 922 & 0.1 & 0.0 \\
\hline GT/MDO & 5.7 & 4.7 & 8.7 & 922 & 0.1 & 0.0 \\
\hline \multicolumn{7}{|c|}{ Manoeuvring / at berth } \\
\hline SSD/MGO & 13.6 & 11.3 & 0.8 & 647 & 1.8 & 0.9 \\
\hline SSD/MDO & 13.6 & 11.3 & 6.2 & 647 & 1.8 & 1.2 \\
\hline MSD/MGO & 10.6 & 8.8 & 0.9 & 710 & 1.5 & 0.9 \\
\hline MSD/MDO & 10.6 & 8.8 & 6.8 & 710 & 1.5 & 1.2 \\
\hline GT/MGO & 2.9 & 2.4 & 1.3 & 1014 & 0.5 & 0.5 \\
\hline GT/MDO & 2.9 & 2.4 & 9.6 & 1014 & 0.5 & 0.7 \\
\hline
\end{tabular}


Table 4 AE emission factors (g/kWh) 'at sea', 'manoeuvring, 'at berth', [8]

\begin{tabular}{|c|c|c|c|c|c|c|}
\hline Engine type/fuel type & $\mathbf{N O}_{\mathbf{x}}$ pre-2000 engine & $\mathbf{N O}_{\mathbf{x}}$ post-2000 engine & $\mathbf{S O}_{2}$ & $\mathbf{C O}_{2}$ & $\mathbf{V O C}$ & $\mathbf{P M}$ \\
\hline $\mathrm{M} / \mathrm{H} \mathrm{SD} / \mathrm{MGO}$ & 17.0 & 14.1 & 0.7 & 588 & 0.4 & 0.3 \\
\hline $\mathrm{M} / \mathrm{H} \mathrm{SD} / \mathrm{MDO}$ & 17.0 & 14.1 & 5.6 & 588 & 0.4 & 0.4 \\
\hline $\mathrm{M} / \mathrm{H} \mathrm{SD} / \mathrm{RO}$ & 14.7 & 12.2 & 12.3 & 722 & 0.4 & 0.8 \\
\hline
\end{tabular}

\subsection{Emission Factors}

Data for the emission factors of the certain pollutants have been obtained from the ENTEC ship emissions inventory study [8] (tables 3 and 4). The emission factors depend on the type of engine (main and auxiliary), fuel used, the engine load factor and the ship's activity. In order to determine $\mathrm{NO}_{\mathrm{x}}$ emission factor, the engine construction year has also been taken into consideration (before/after 2000). This is because the engines installed after 2000 have to satisfy IMO Technical Code for reducing $\mathrm{NO}_{\mathrm{x}}$ emission [24]. Unlike main engine, the emission factor for the auxiliary engine is equal for all ship's activities.

\subsection{Time Activities}

The estimated cruising time (in hours) refers to time from the start of pilotage to the point of entering the port, i.e. to the port breakwater. Time is calculated according to the ratio of the trip's length (in kilometres) and the ship's arithmetic average speed in reduce speed zone $(\mathrm{km} / \mathrm{h})$. Cargo ships calculated speed amounts 9 knots $(16.67 \mathrm{~km} / \mathrm{h})$ and cruise ships 11 knots $(20.37 \mathrm{~km} / \mathrm{h})$. The cruising time to the port for cruise ships is 3.20 (h) and 3.92 (h) for cargo ships. The ship arriving and departing cruising time is included in calculation. The average manoeuvring time is 1 hour for all types of ports and ships [7]. However, this data depend on the dimensions of ships and the port locations. Thereby, average manoeuvring time is calculated as follows: 2 hours for tankers (due to placing of additional safety breakwaters), 1 hour for general and bulk cargo ships and 0.8 hour for cruise ships. Manoeuvring time implies a total time of ships arrival and departure.

Ship hotelling hours imply a total time spent at berth. According to the data from Port of Zadar Authority for each cruise ship, overall hotelling time is determined throughout year. Since there are not accurate data for cargo ships, the average hoteling time from ENTEC study [7] (without manoeuvring time) has been used. The average hoteling time for general cargo and tankers is 38 hours, 23 hours reefers and 13 hours for self-discharging bulk carriers.

\section{Results}

The total annual emission for cargo ships is 55.89 $\mathrm{t}$ for $\mathrm{NO}_{\mathrm{x}}, 3.76 \mathrm{t}$ for $\mathrm{SO}_{\mathrm{x}}, 3.5 \mathrm{t}$ for VOC and $1.38 \mathrm{t}$ for PM (Figure 2). The types of emissions depend on the type of the pollutant and the activity of a ship (cruising, manoeu- vring and hotelling), out of which cruising and hotelling are the longest phases. The auxiliary engines cause cargo ships emissions during hotelling, but due to longer port stay, they are becoming considerably closer in numbers to those coming during cruising.

The total annual cruise ships emissions (Figure 3.) amounts to $310.23 \mathrm{t}$ for $\mathrm{NO}_{\mathrm{x}^{\prime}} 24.91 \mathrm{t}$ for $\mathrm{SO}_{\mathrm{x}^{\prime}}, 14.16 \mathrm{t}$ for VOC and $9.62 \mathrm{t}$ for PM. The prevailing emission is from the cruising phase due to spending less time in the port.

The cruise ships emission is much higher than the cargo ships emission because of greater number of ships arriving to the port. The total annual emission is the sum of obtained results: $366.12 \mathrm{t}$ for $\mathrm{NO}_{\mathrm{x}}, 28.67 \mathrm{t}$ for $\mathrm{SO}_{\mathrm{x}}, 17.71 \mathrm{t}$ for VOC and $11.15 \mathrm{t}$ for PM. However, the NO emission has been estimated on the basis of allowable value in accordance with the $\mathrm{NO}_{\mathrm{x}}$ Technical Code and with assumption that technologies for reducing $\mathrm{NO}_{\mathrm{x}}$ have not been installed on any cargo or cruise ship, so calculated $\mathrm{NO}_{\mathrm{x}}$ emission should be considered below this value.

$\mathrm{CO}_{2}$ emissions are presented in Figure 4. for both, cargo and cruise ships. The annual $\mathrm{CO}_{2}$ emission for cargo ships amounts to $3031.15 \mathrm{t}$ and $19529.38 \mathrm{t}$ for cruise ships. The

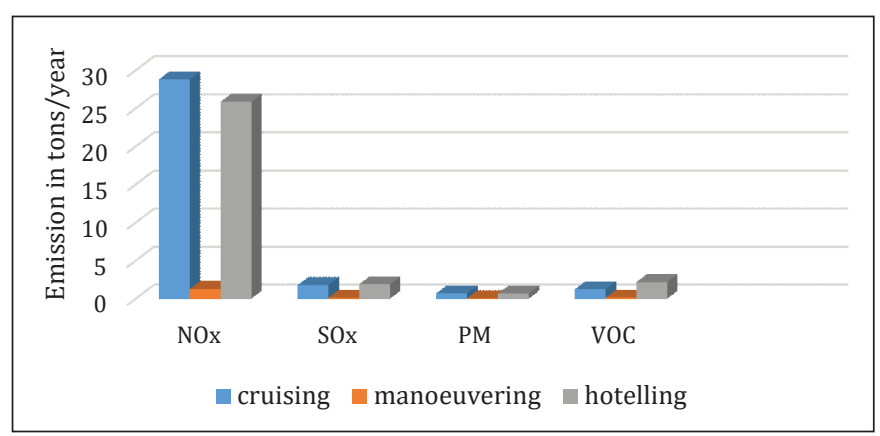

Figure 2 Cargo ships emission (tons/year)

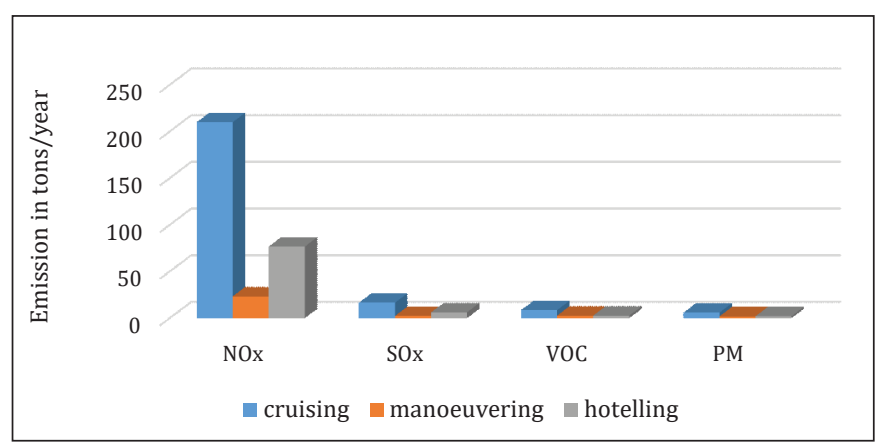

Figure 3 Cruise ships emission (tons/year) 


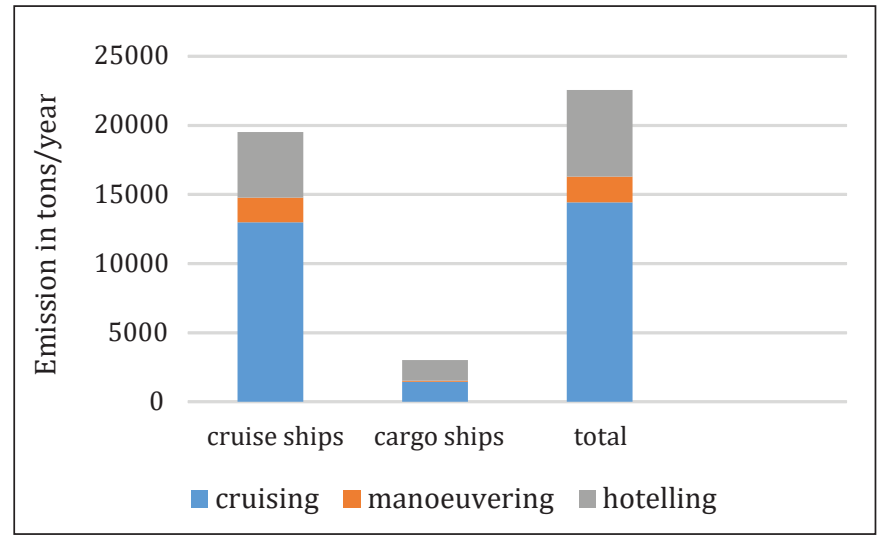

Figure 4 Total $\mathrm{CO}_{2}$ emission (tons/year)

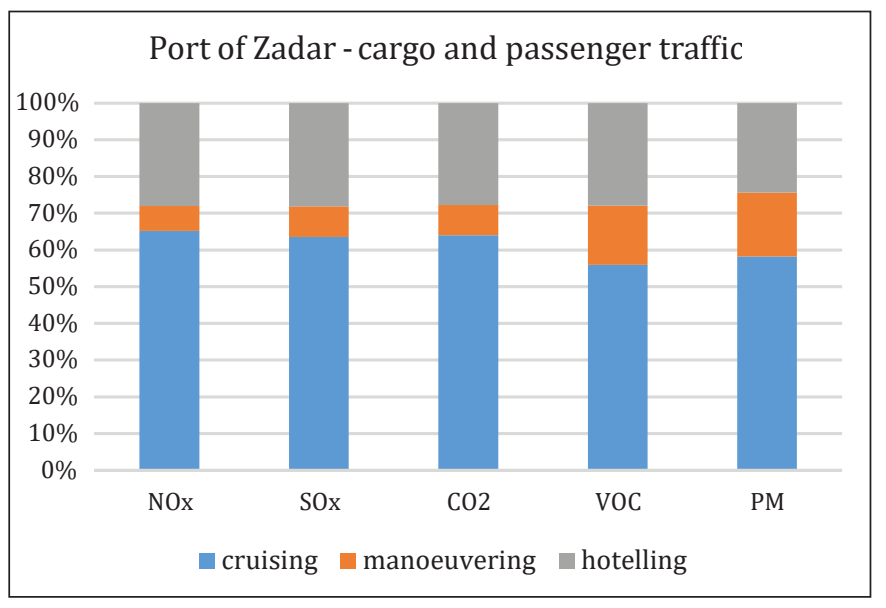

Figure 5 Ship emission for specific activities

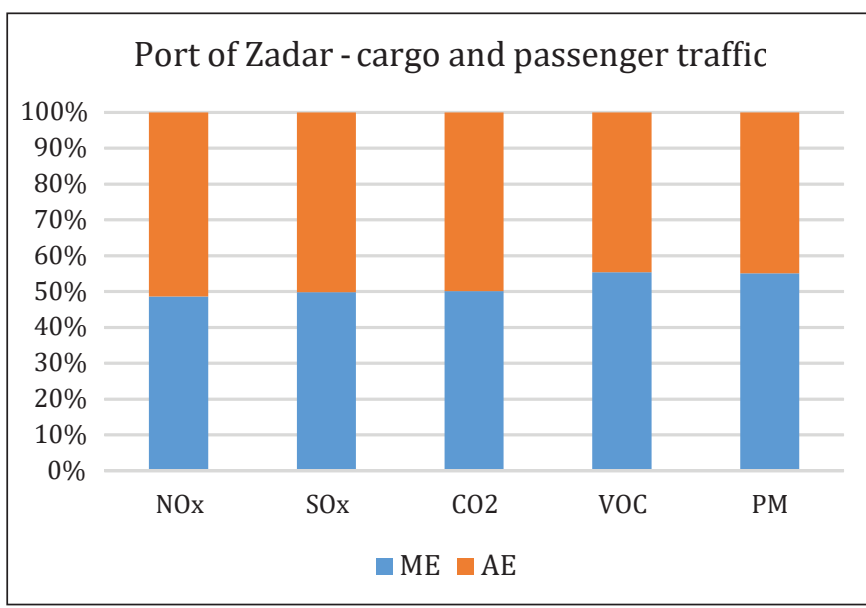

Figure 6 Main engine (ME) and auxiliary engine (AE) emission

total annual amount of $22560.53 \mathrm{t}$ ( $22.56 \mathrm{kt}$ ) is the result of their sum. Cargo ships emitted $1506 \mathrm{t}$ of $\mathrm{CO}_{2}$ during hotelling, whereas, during cruising and manoeuvring the emission was 1450 tons. The prevailing cruise ships emission was 12991.55 t during cruising, whereas, during hotelling, it was $4749 \mathrm{t}$ because of the auxiliary engines' load factor.

\section{Discussion}

Figure 5 presents ship emission for specific activities. Some $55-65 \%$ refer to cruising emission, $25-30 \%$ to hotelling emission, whereas $5-10 \%$ refer to manoeuvring. The results show that most of the emission comes during cruising, whereas, a significant part is the result of hotelling. The emission percentage for these activities varies depending on the type of port, terminal or marine traffic. The annual cruise ships emission (80\%) is significantly higher than the cargo ships emission (20\%) primarily as the result of greater number of dockings at the passenger terminal.

The emission from the main and auxiliary engines is shown in the Figure 6. Main engines enable ship's propulsion and emit mostly while cruising. The auxiliary engines serve as providers of electric power and emit mostly during hotelling and manoeuvring because of the greater load factor. It can be noticed that, depending on the type of the pollutant, the portion of $\mathrm{NO}_{\mathrm{x}}$ for the auxiliary engines is slightly higher than for the main engines, and amounts to $53 \%$. The portions of $\mathrm{SO}_{\mathrm{x}}$ and $\mathrm{CO}_{2}$ are almost the same, whereas, the portions of VOC and PM for the main engines are higher and amount to 55\%.

Some studies, [3], take into account the boiler emission as well. However, it has turned out that they emit less than $5 \%$ of the total emission. In the absence of data on power and the type of boilers, their emission was not taken into account when calculating the emission.

\section{Conclusion}

This research has assessed the emission inventory from ships in marine traffic for the port of Zadar, which is one of the most relevant maritime destinations on the Adriatic Coast. The total marine traffic in the port of Zadar for 2017 included 108 cruise ships dockings and 78 cargo ships dockings. The methodology of creating the emission inventory includes data on the characteristics of the ship, such as the power of the main and auxiliary engines, the type of fuel, the load factor, time of cruising and hotelling. A detailed analysis has given the results for the annual emission, in tons, for $\mathrm{NO}_{\mathrm{x}}, \mathrm{SO}_{\mathrm{x}}, \mathrm{CO}_{2}, \mathrm{VOC}$ and PM. The results (tons/year) have shown that approximately $80 \%$ of the total annual emission comes from passenger ships and $20 \%$ from cargo ships. These have been the result of both, the growth of cruise ships tourism in the passenger port, and the fact that Zadar has become an important tourist destination. The exhaust gas emissions mostly come during cruising and hotelling, which together, makes 85-90\% of the total emission. The total annual emission in tons amounts to $366 \mathrm{t}$ for $\mathrm{NO}_{x^{\prime}}, 28 \mathrm{t}$ for $\mathrm{SO}_{x^{\prime}} 22.5 \mathrm{kt}$ for $\mathrm{CO}_{2^{\prime}}, 14 \mathrm{t}$ for VOC and $9 \mathrm{t}$ for PM.

The planned expansion of the port's infrastructure and the construction of the new container terminal will result in the growth of traffic and exhaust gas emission. The new terminals will have a significant influence on the emission inventory and the growth of the local expenses. The port's 
infrastructure has to be in accordance with sustainable development and it has to be functional both ecologically and economically, with every future research heading in that direction.

\section{References}

[1] Badurina P., Cukrov M., Dundović Č., Contribution to the implementation of "Green Port" concept in Croatian seaports // Pomorstvo, Vol 31 (pp. 10-17), 1; 2017.

[2] Cuculić A., The implementation of high-voltage shore connection in Croatian ports, Pomorstvo, Scientific Journal of Maritime Research Vol 27 (pp. 105-116), 2013.

[3] Dongsheng C., Yuehua Z., Nelson P., Yue L., Xiaotong W., Estimating ship emissions based on AIS data for port of Tianjin, China, Atmospheric Environment Vol 145, (pp. 10-18), 2016.

[4] Dragovic' B., Ship emissions and their externalities in cruise ports. Transport. Res. Part D Vol 61, (pp. 289-300), 2018.

[5] Endersen 0., Sørgard E., Emission from international sea transportation and environmental impact, Journal of Geophysical Research, Vol 108, no. D17, 2003.

[6] EMEP/EEA, Air pollutant emission inventory guidebook 2009, Published by EEA (European Environment Agency), Technical report No 9/2009.

[7] ENTEC, 2002. Quantification of Emissions from Ships Associated with Ship Movements between Ports in the European Community. Final Report, July 2002. Prepared for the European Commission.

[8] ENTEC UK Limited, November 2010, UK. Ship Emissions Inventory. Final Report.

[9] ICF, Consulting. Current Methodologies and Best Practices in Preparing Port Emission Inventories. EPA, Fairfax, Virginia, USA. Final Report for U.S., 2006.

[10] Jalkanen, J.P., Brink, A., Kalli, J., Pettersson, H., Kukkonen, J., Stipa, T., A modelling system for the exhaust emissions of marine traffic and its application in the Baltic Sea area. Atmos. Chem. Phys. 9, (pp. 9209-9223), 2009.

[11] Lenac, K., Methods of reducing harmful pollutants from ships, Pomorstvo: Scientific Journal of Maritime Research, Vol 19 (pp 11-27), 2005.
[12] Merk O., Shipping Emissions in ports, Discussion Paper no. 20, 2014.

[13] Papoutsoglou T. G., A Cold Ironing Study on Modern Ports, Implementation and Benefits Thriving for Worldwide Ports, School of Naval Architecture \& Marine Engineering, 2012.

[14] Radonja R., Cuculić A., Valčić M., Introducing the ASAP project (Adriatic Sea Area Protection) // Pomorstvo: Scientific Journal of Maritime Research, Vol 25 (pp. 319-341), 2011.

[15] Song S., Ship emissions inventory, social cost and eco-efficiency in Shanghai Yangshan port, Atmospheric Environment Vol 82 (pp. 288-297), 2014.

[16] Styhrea L.,Winnesa H., Black J., Jimyoung L., Le-Griffin H., Greenhouse gas emissions from ships in ports - Case studies in four continents, Transportation Research Part D: Transport and Environment Vol 54, (pp. 212-224), 2017.

[17] Trozzi C., Update of Emission Estimate Methodology for Maritime Navigation, Techne Consulting SRL, report ETC. EF.10 DD, May 2010.

[18] Tzannatos E., Ship emissions and their externalities for the port of Piraeus - Greece, Atmospheric Environment Vol 44 (pp. 400-407), 2010.

[19] Vujičić A., Jerman B., Zrnić N., Ports Sustainability: A life cycle assessment of Zero Emission Cargo Handling Equipment: Strojniški vestnik, 2013.

[20] WHO: Health effects of particulate matter, regional office for Europe, 2013.

[21] Zhang Y., Yi-qiang P., Wang W., Air emission inventory of container ports' cargo handling equipment with activitybased "bottom-up" method: Advances in Mechanical Engineering Vol 9, 2017.

[21] http://www.scheepvaartwest.be (9 October 2018)

[22] http://www.port-authority-zadar.hr (11 October 2018)

[23] https://www.lr.org/en/fuel-testing/ (11 October 2018)

[24] http://www.imo.org/en/MediaCentre/HotTopics/Pages/ Sulphur-2020.aspx (6 October 2018)

[25] www.europeanbestdestinations.com/best-of-europe/(16 October 2018) 